\title{
THE EVOLUTION OF THE APPROACH OF THE STATE AUTHORITIES TO MINORITIES AND ETHNIC GROUPS IN THE THIRD REPUBLIC OF POLAND (OUTLINE OF ISSUES)
}

\author{
by Ewa Waszkiewicz
}

The new borders and new ideology imposed on Poland in the aftermath of World War II significantly affected the ethnic structure of the state and the approach of its communist authorities towards minority groups.

The pre-war Poland was a multi-national state where Poles represented about $69.2 \%$ of the population, the remaining $30.8 \%$ were the members of minorities - with the biggest communities of Ukrainians, Belarusians, Germans and Jews.

According to the first, official, post-war census - the minority groups represented after 1945 already only $2 \%$ of the citizens of new Poland. ${ }^{1}$

The policy of the state in which the communists took power intended to discredit the fact that the citizens who differed from the majority in respect of nationality, language or religion also lived in Poland. The course of policy towards minorities was set by the political authorities that wanted to build a state which would be uniform in respect of nationality. The approach of the state to the Jews, Germans, Ukrainians, Lithuanians, Belarusians, Rusyns or Roma living in Poland was varied, inconsistent and ambiguous. ${ }^{2}$

The post-war displacements of Germans, "Operation Wista" against Ukrainians, the Kielce Pogrom or finally March 1968 Events, resulting in the citizens belonging

${ }^{1}$ K. Kersten, Przemiany struktury narodowościowej Polski po II wojnie światowej. Geneza i wyniki, "Kwartalnik Historyczny" 1969, No. 2, p. 365.

2 Compare: E. Mironowicz, Polityka narodowościowa PRL, Białoruskie Towarzystwo Historyczne, Białystok 2000. 
to minorities leaving Poland, mobilized the authorities of the ruling Polish United Workers' Party (PZPR) to promote the idea of a nationally uniform character of Polish society which ultimately resulted in the resolution of the Third Assembly of PZPR Central Committee on "moral and political unity of the Polish nation" adopted in 1976.

In the times of the People's Republic of Poland (PRL) the rights of minorities were administratively restricted and their scope depended on political tensions and turning points in Poland and in the world. The authorities were trying to erase ethnic differences, ignoring and underestimating the needs of minority groups often considering assimilation as a remedy to solv the problems of minorities.

Despite the 'whimsical' and inconsistent policy of PRL's authorities towards minorities, those communities were able to use the periods of a more favorable treatment and create with the approval of the authorities their own social and cultural associations ${ }^{3}$, publish their own press or obtain financial support for native language courses in schools.

After the analysis of political decisions of the state and the administratively restricted rights and freedoms for minorities one should agree with the opinion that “(...) the overall result of the nationality policy of PRL's authorities was unbeneficial for both national minorities and Polish state. As a result of resettlements, emigration or assimilation all groups of population other than Polish suffered losses. The state lost hundreds of thousands of citizens - often most active - who created permanent material and spiritual values with their work. Neither national prejudices nor xenophobia disappeared and instead of historical knowledge young people at school were offered national mythology. " $^{\prime \prime}$

The transformation of political system in Poland in 1989 started the stage of a qualitatively completely new state policy towards national minorities because the 'philosophy' of the authorities' approach to the issues of minorities changed dramatically.

The researchers of the issues of minorities agree that the process of recognition of national minorities as separate groups in the state began in Poland earlier, before 1989 and that it was connected first of all with the creation of "Solidarity" movement in 1980 .

During the national convention of the delegates of "Solidarity" in Gdańsk in 1981 a special resolution was adopted: "Caring for the development of Polish culture open to the heritage of other nations, we wish to express the will to apply at least as much

${ }^{3}$ Gestern, Heute, Morgen, 50 Jahre Deutsche Sozial - Kulturelle Gesellschaft in Niederschlesien, Niemieckie Towarzystwo Społeczno-Kulturalne we Wrocławiu, Wrocław 2007, p. 140.

${ }^{4}$ E. Mironowicz, Polityka narodowościowa, op.cit, p. 266. 
care so that Polish citizens belonging to other nations and ethnic groups - Belarusians, Gypsies, Greeks, Lithuanians, Rusyns, Germans, Ukrainians, Tatars, Jews and other nationalities could find the conditions to freely develop their culture and pass it on the next generations in the country shared with Poles. ${ }^{5}$

At the end of the 1980s in the middle of ongoing changes and the revival of citizens' activity, the still socialist Sejm of the 10th Term of Office adopted an exceptionally significant act for national and ethnic minorities - the act on freedom of conscience and religion ${ }^{6}$ which gave churches and religious organizations previously non-existent rights.

The establishment of the Sejm Committee for National and Ethnic Minorities with the representatives of all those social groups on Aug. 2, 1989 in that very Sejm of the 10th Term of Office was a momentous event. It was a very important fact for the life of minorities; for the first time after 1945 the representatives of the constituencies where members of minorities lived became Members of Parliament.

The following comment made by Tadeusz Mazowiecki, the first non-communist Prime Minister, on Sept. 12, 1989 became the essence of the philosophy of the new state: "Poland is a state, a homeland of not only Poles. We live on this earth with the members of other nations. We want them to feel at home, cultivate their language and enrich our community with their culture.?"

Along with the change of the state approach to national minorities there came quick institutional changes - reorganization of offices which would be responsible for the issues of minorities.

This process, as described then by the political press, was supposed to reflect the state support and assistance for the minorities and not the control and administrative distribution of rights from the times of PRL.

Establishing new offices and raising various problems of minorities on the central forum, the Polish state with growing democracy performed a sui generis act of 'recognition' of minorities and building the foundation of a new system it confirmed a positive attitude to pluralism, distinctness or ambitions of national groups.

At the same time, as emphasized by researchers, a feedback developed; the representatives of minority groups began to stress their ethnic distinctness, express their sense of pride with this distinctness and bravely formulate postulates to the new state.

${ }^{5}$ K. Podlaski, Białorusini, Litwini, Ukraincy, "Versus”, Białystok 1990, p. 124.

${ }^{6}$ Act from May 17, 1989 on guarantees of freedom of conscience and religion, "Journal of Laws" 1989, No. 29, item 155, as amended.

7 S. Łodziński, Równość i różnica, Mniejszości narodowe w porządku demokratycznym w Polsce po 1989, Wydawnictwo Naukowe Scholar, Warsaw 2005, p. 124. 
In autumn 1989, at the level of central government administration the minority issues were transferred by from the Ministry of Internal Affairs to the Ministry of Culture and Art and the Ministry of Foreign Affairs.

By the Resolution of the Council of Ministers no. 142 from Sept. 7, 1990 the Committee for National Minority Issues was established at the Ministry of Culture and Art. It was supposed to advise the Council of Ministers on minority issues. In June 1997, after reorganization the name of the Committee was changed to the InterMinisterial Team for National Minority Issues and in February 2002 Team for National Minority Issues. The ordinance no. 49 of the Chairman of the Council of Ministers of June 20, 1997 was the basis of the establishment of the Team. The members of the Team included persons representing the Ministry of Culture and Art, the Ministry of National Education, the Ministry of Justice, the Ministry of Foreign Affairs, the Ministry of Finance, the Ministry of Labor and Social Policy as well as representatives of the Council for Remembrance of Struggle and Martyrdom and the Central Statistical Office. The Team was a collegial body providing Prime Minister with opinion and advice on setting the directions of policy and activities of the government regarding national minorities. The Commissioner for Civil Rights Protection also started to deal with the protection of the rights of minorities, reacting to complaints of the minorities.

Further reorganization of central administration resulted in transfer of national minority issues to the Ministry of Internal Affairs and Administration (MSWiA) where the Division of National Minorities was established in January 2000 which after another regulation was assigned to the Department of Religious Denominations, National and Ethnic Minorities of MSWiA. The Department dealt with the relations between the state and churches, religious organizations, Church Fund and cooperation with the Social Insurance Institution, insurance of clergy, national and ethnic minorities as well as regional languages (since 2005), register of operating churches and religious organizations, official register of municipalities (gminas) in which an auxiliary language was recognized, register of gminas in which the introduction of bilingual names was allowed, and after the Joint Committee of the Government and National and Ethnic Minorities was established it also dealt with organizing meetings of this entity.

The department was entrusted with the monitoring of the execution of the governmental programs for the national and ethnic minorities, execution of such programs and finally the development of proposals of solutions regarding the support by the government administration of operations aiming at the protection, preservation and development of the identity and culture of national and ethnic minorities as well as preservation and development of regional languages.

The government - local administration was also assigned the tasks connected with the protection of national minorities. Art. 22 of the Act on National Minorities 
ordered the governors (voivodes) to coordinate the activities of the entities performing the "tasks for the benefit of minorities," undertake anti-discriminating activities, protect the rights of persons using the language of minorities.

In some provinces (voivodeships) - (Art. 22 pt. 3 of the Act - "voivode can appoint a plenipotentiary") plenipotentiaries were appointed for the issues of national and ethnic minorities 8 . Where no plenipotentiaries of voivodes were appointed, persons holding other positions were entrusted with the minority issues.

Along with the administrative reform of the state in 1990 and 1998 and the new division into local units, both gminas and counties (powiats) were assigned statutory tasks to protect and care for local culture - which became especially important also for the minorities living in those areas.

In 2002, 46 years after the first and only census taking into account the nationality structure of Poland (February 1946,) the National Census was conducted in Poland. The questions with which the researchers tried to establish the nationality of the inhabitants were as follows: 1 . What nationality are you? 2. In what language(-s) do you speak most often at home?

The results of the census caused a lot of controversies among both representatives of national minorities and scientists and both its methods as well as results were questioned 9 .

"Generally [the minorities] agreed that it captured only the number of organized members of a given group and the persons most aware of their nationality, independent and not exposed to negative effects of their nationality declaration." 10

Although the data provided by the census shall be approached very carefully, the results did become an indicator for the authorities executing the state policy towards the minorities living in Poland.

According to the data collected in the census the belonging to national and ethnic minorities was declared by 48.7 thousand Belarusians, 0.8 thousand Czechs, 0.05 thousand Karaites, 5.8 thousand Lithuanians, 5.9 thousand Rusyns, 152.9 thousand Germans, 1.1 thousand Armenians, 12.9 thousand Roma, 6.1 thousand Russians,

${ }^{8}$ In 2008, 9 out of 16 regions had their voivode plenipotentiaries for national and ethnic minorities: Lower Silesian Voivodeship, Lubuskie Voivodeship, Łódzkie Voivodeship, Lesser Poland Voivodeship, Sub-Carpathian Voivodeship, Podlaskie Voivodeship, Warmian-Maurian Voivodeship, Greater Poland Voivodeship, West Pomeranian Voivodeship.

9 Compare: L. Adamczuk, S. Łodźiński, Mniejszości narodowe w Polsce w świetle Narodowego Spisu Powszechnego z 2002, Wydawnictwo Naukowe Scholar, Warsaw 2006.

10 E. Michalik, H. Chałupczak, Mniejszości narodowe i etniczne w procesach transformacji oraz integracji, Wydawnictwo Uniwersytetu Marii Curie-Skłodowskiej, Lublin 2006, p. 263. 
2 thousand Slovaks, 0.5 thousand Tatars, 31 thousand Ukrainians, 1.1 thousand Jews $^{11}$.

In relation to the whole population the minorities in 2002 according to the results of the census represented $1.5 \%$ of the society. Other data can be found in the document made by MSWiA for the Council of Europe ${ }^{12}$. In the Report (page 9) it says that 253,273 people belong to national and ethnic minorities, which represents $0.7 \%$ of Polish citizens.

Along with ongoing institutional changes new legal acts were adopted which were to help in realizing the democratic vision of the state policy towards minorities.

The international obligations - signed by Poland still during the rule of PRL in the form of multilateral agreements ${ }^{13}$ as well as bilateral agreements concluded already by new authorities had a great effect on the shape of legal solutions developed by new authorities of the Republic of Poland.

The bilateral agreements - to mention just those concluded with direct neighbors - Federal Republic of Germany in 1991, Czech and Slovak Republics in 1991, Ukraine, Russian Federation and Republic of Belarus in 1992 and the Republic of Lithuania in 1994 guaranteed a broad catalog of rights for persons who belong to national minorities. ${ }^{14}$

Among the whole myriad of guarantees the following rights can be listed: the right to equality, nondiscrimination, the right to learn in native language, use names in original language, practice and cultivate religion, establish and operate organizations and associations, maintain contacts with members of minorities in Poland and abroad.

The provisions of the new Polish constitution reflected the international solutions and changes in the internal policy of the state.

The inclusion of the provisions regarding the protection of national minorities already in the second Chapter of the Constitution - titled "The Freedoms, rights and

11 A. Malicka, Ochrona mniejszości narodowych - standardy międzynarodowe i rozwiązania polskie, Wydawnictwo Uniwersytetu Wrocławskiego, Wrocław 2004, p. 89.

12 2nd Report for Secretary General of the Council of Europe from the enforcement by the Republic of Poland of the provisions of the Framework Convention for the Protection of National Minorities, Warsaw 2007.

13 The following examples should be listed here: Universal Declaration of Human Rights, UNESCO Convention against Discrimination in Education, International Convention on the Elimination of All Forms of Racial Discrimination, International Covenant on Civil and Political Rights as well as legal regulation regarding exclusively minorities - Framework Convention of the Council of Europe for the Protection of National Minorities ratified by Poland in 2000.

14 A. Malicka, Ochrona mniejszości narodowych..., p. 121 and n. 
obligations of persons and citizens" demonstrates how great significance the authorities of the new, democratic state attached to that protection.

For the sake of comparison it should be pointed out here that the socialist Constitution of July 22, 1952 included the provision on equal treatment of all citizens regardless of sex, birth, education, profession, nationality, race, religion, origin or social situation ${ }^{15}$ and forbade under penalty discrimination in all areas of state, political, economic, social or cultural life against nationality, race or religion ${ }^{16}$.

There was no provision on the existence of or need to protect the national minorities; furthermore, PRL's authorities did not respect those declarations and the practice applied was far from the adequate wording of the principles ${ }^{17}$.

According to the new policy of the state towards national minorities, the provisions of the Constitution from 1997 included exspresis verbis the recognition of those social groups and grant them special rights but they still had individual character.

Art. 35 of the Constitution provides that:

"1. The Republic of Poland shall ensure Polish citizens belonging to national or ethnic minorities the freedom to maintain and develop their own language, to maintain customs and traditions, and to develop their own culture."

2. National and ethnic minorities shall have the right to establish educational and cultural institutions, institutions designed to protect religious identity, as well as to participate in the resolution of matters connected with their cultural identity."

Such a provision clearly indicated that the state undertakes activities which shall support minorities in exercising the rights to maintain their own cultural identity, language or religion.

At the same time the creators of the constitution preserved the structure of the guarantee of individual rights for members of national and ethnic minorities ${ }^{18}$.

New acts and enforcement laws - ordinances served to perform the provisions of the Constitution.

Without going into detailed analysis of their provisions now and without listing all legal regulations, the following are examples of the regulations divided by the kind of rights they guarantee for minorities:

15 Art. 67, subpar. 2, "Journal of Laws" 1952, No. 33, item 232.

16 Art. 69 of the Constitution of the People's Republic of Poland: "1. The citizens of irrespective of nationality, race and religion shall have equal rights in all areas of state, political, economic, social and cultural life. Any violation of this principle by any direct or indirect privilege or restriction of the rights due to nationality, race or religion shall be subject penalty."

17 Compare: M. Pietrzak, Prawo wyznaniowe, Warsaw 1999.

18 S. Łodziński, Równość i różnica..., op.cit., p.143. 
- The rights in the scope of religion for denominational minorities - earlier mentioned Act on Guarantees of Freedom of Conscience and Religion of May 17, $1989^{19}$, Ordinance of the Ministers of Labor and Social Policy and National Education on exemptions from work or school for persons belonging to churches or religious organizations in order to celebrate religious holidays which are not statutory holidays of March 11, 1999 or the Announcement of the Minister of Internal Affairs and Administration of 1998 listing the positions in churches and religious organizations whose holders are entitled to solemnize the marriage resulting in civil and legal effects ${ }^{20}$.

The Announcement listed 11 churches and religious organizations - including the Roman Catholic Church.

Furthermore, the state issued over a few years numerous acts regulating the relation of the authorities to specific religious organizations - good examples include the following: the Act on the Relation of the State to the Polish Catholic Church in the Republic of Poland (June 30, 1995,) the Act on the Relation of the State to the Old Catholic Mariavite Church in the Republic of Poland (February 20,1997) or the Act on the Relation of the State to the Jewish Communities in the Republic of Poland (February 20, 1997.)

The number of registered new churches, religious organizations and associations dramatically increased after 1989, becoming a confirmation of the implementation of the process of democratization of the state and a positive attitude of its authorities towards national and ethnic minorities.

In 2008, there were already 149 registered churches and religious organizations as well as 5 religion-oriented associations in Poland.

- The language rights were secured by the following - the Act on Educational System of Sept. 7, 1991 and the Ordinance of the Minister of National Education on organizing education providing for preservation of the sense of national, ethnic and language identity of school children from national minorities of March 24, 1992.

The provisions of the Broadcasting Act of Dec. 29, 1992 reflected the state respect for ethnic distinctness: "public radio and television programs (...) shall take into account the needs of national minorities and ethnic groups."

- The cultural rights - apart from the acts referred to above, the following became the basis for securing those rights - the state expenses in the form of subsidies for cultural events organized by minority associations. "Under the (...) patronage of the state national minority organizations issue magazines, manage artistic groups and

19 Unified text "Journal of Laws" 2000, No. 26, item 39; "Journal of Laws" 1999, No. 26, item 235

20 Announcement of the Minister of Internal Affairs and Administration from Nov. 4, 1998, "Monitor Polski” 1998, No. 40, item 554 
education and popularization operations s $^{21}$." In 2008 , the state budget earmarked about PLN 14 million for the needs of minorities.

- The political rights - the 'recognition' of minorities by the authorities of new Poland meant also granting the members of those communities the rights to participate in political life of the country.

The Act of April 12, 2001 introduced new electoral regulations to the Sejm and the Senate of the Republic of Poland which mentioned expresis verbis that "the electoral committees created by voters associated in registered national minority organizations can use the exemption of the lists of those committees from the conditions referred to in Art. 133 subpar. (... 22." The registered minority committees did not have to reach the $5 \%$ vote threshold. This exemption regarded only the elections to the Sejm.

Although the Polish state did not grant national and ethnic minorities any special preferences in the local government acts (1990 and 1998), in the next local elections the representatives of those groups were elected to the authorities of gminas or powiats - in fact in the areas where they were in quantitative majority compared to Polish community they took most seats.

It has become clear already over a number of years that the authorities of new Poland 'have been learning how to deal' with minorities and the following reforms of offices and new legal acts were the response to the search of a good and effective policy toward the non-Polish communities.

Furthermore, the national and ethnic minorities fully recognized and empowered by the state formulated new demands from the authorities through heir leaders.

The Act on national and ethnic minorities and regional language of Jan. 6, 2005 was another legal act enabling the implementation of the state policy ${ }^{23}$.

The work on the act began in the 1980s and its final shape was a compromise between the postulates of minorities and political concepts of the state authorities.

Continuing the guarantees provided by the Constitution of the Republic of Poland of 1997 and the provisions of international law ratified by Poland, including the Framework Convention for the Protection of National Minorities ${ }^{24}$ or applicable Council Directive 2000/43/EC of June 29, 2000 on equal treatment between persons irrespective of racial or ethnic origin, the act of 2005 introduced a number of new solutions.

${ }^{21}$ S. Łodziński, Równość i różnica..., op.cit., p. 178.

22 According to this article the electoral committees registered by national minority associations were released from the obligation of reaching $5 \%$ of the votes.

23 "Journal of Laws" 2005, No. 17, item 141.

24 “Journal of Laws" 2002, No. 22, item 209. 
Defining the notion of "national minority" and "ethnic minority" was a total novelty. None of the legal acts of the Polish internal law had defined those terms earlier.

Art. 2 of the act defined a national minority as a group of Polish citizens that while being in quantitative minority is "significantly distinct from other citizens by its language, culture or tradition," strives to maintain those values, is aware of its own historical community and protects it, has been living for at least 100 years on the territory of the Republic of Poland and identifies itself with the nation "organized in its own state." The act enumeratively listed the following national minorities living in Poland: Belarusian, Czech, Lithuanian, German, Armenian, Russian, Slovak, Ukrainian, Jewish."

The act defined an ethnic minority as a group of citizens that is quantitatively smaller than and distinct from other citizens by its language, culture or tradition, strives to maintain those values, is aware of its own historical ethnic community, has been living for at least 100 years on the territory of the Republic of Poland and does not identify itself with the nation organized in its own state. As defined in this way the act included the following in the group: Karaite, Rusyn, Romani and Tatar minorities.

The only criterion then distinguishing both communities in the definition is that "one identifies itself with the nation organized in its own state and the other does not."

Assuming the definition is subjective, the act in Art. 4 guaranteed everybody freedom to decide on the belonging to a minority.

What became the object of the regulations of the act was - according to Art.1 "the matters connected with the maintaining and developing of the cultural identity of the national and ethnic minorities as well as maintaining and developing the regional language and the way of enforcing the principles of equal treatment among persons irrespective of ethnic origin." Article 1 entrusted central and local administration with the execution of those tasks.

The act guaranteed freedom to decide on the belonging to a minority (Art. 4,) it forbade the activities aiming at assimilation (Art. 5) and forbade the discrimination against personsbelonging to a minority (Art. 6.)

The act introduced a number of additional rights in the scope of using a minority language and guaranteed the right to use an auxiliary language - "apart from official language a minority language can be used as an auxiliary language before the bodies of gmina" (Art. 9.)

At the same time a provision was introduced which stipulated that an auxiliary language can be used in gminas in which minorities represent at least $20 \%$ of the whole population.

The provision of the regional language was another novelty - Art. 19 print 2 provided that: "In the meaning of the act Kashubian language is a regional language." 
Its use and learning was subjected to the provisions included in the paragraph of the act: "the use of a minority language. ${ }^{25}$ " It is worth adding that 4.478 school children were learning in 104 educational institutions Kashubian language in the school year $2005 / 2006^{26}$.

The reflection of new rights granted to minorities was Art.12 of the act - providing for the introduction of additional, traditional names in minority language - in the names of towns, streets and physical and graphical objects. The act also introduced a provision granting such a right to gminas with at least $20 \%$ of the inhabitants belonging to minorities. There was a new provision in the act guaranteeing the right to officially write the first and last names according to the spelling rules of native language (Art. 7.)

The act obliged the central and local administration offices - the minister for religious denominations and national and ethnic minorities, voivodes and their plenipotentiaries, local governments of gminas and powiats to enforce the rights of national and ethnic minorities.

The Joint Committee of the Government and National and Ethnic Minorities, providing the Chairman of the Council of Ministers with opinion and advice became a new, statutorily guaranteed body (Art. 23.)

In compliance with the provisions of the act the members of the Committee included the representatives of national and ethnic minorities, representatives of the community speaking in Kashubian language, the President of the Central Statistical Office, a representative of the Council for Remembrance of Struggle and Martyrdom.

The Members of the Committee were appointed by the Chairman of the Council of Ministers at the request of the competent minister for religious denominations and national and ethnic minorities. The representatives of local governments, nongovernmental organizations or the world of science were also invited to participate in the meetings of the Committee.

The Committee whose first meeting was held on Sept. 21, $2005^{27}$ was statutorily appointed to submit opinions on the matters regarding "the performance of the rights

${ }^{25}$ In the National Census from 2002 52,665 persons declared the use of Kashubian at home.

${ }^{26}$ Report for Secretary General of the Council of Europe from the enforcement by the Republic of Poland of the provisions of the Framework Convention for the Protection of National Minorities, Warsaw 2007, p. 35, MSWiA.

27 Already at the first meeting of the Committee the following were appointed: Team for Education, Team for Culture and Media and Team for Romani Issues, the Minutes from the 1st meeting of the Joint Committee of the Government and National and Ethnic Minorities on 21.09.2005, MSWiA 
and needs of the minorities, including the assessment of the way those rights are exercised and formulating proposals in the scope of activities aiming at securing the performance of the rights and needs of the minorities."

The act entrusted the Committee with submitting opinions on legal acts, programs serving the maintaining of the cultural identity of minorities, suggesting the level and the principles of division of expenses from the state budget on minorities as well as "undertaking activities preventing discrimination against persons belonging to minorities."

10 meetings of the Committee were held between 2005 and 2008.

The most important issues discussed at the meetings included those regarding finances and organizational matters.

The representatives of the government would report: "Information on detailed principles of procedure of granting subsidies for the execution of tasks [in the following years] aiming at protecting, maintaining and developing the cultural identity of national and ethnic minorities as well as maintaining and developing the regional language ${ }^{28 .}$."

The representatives of minority organizations would conduct fervent discussions on the principles of the distribution and present their needs and doubts. The leaders of minorities would present problems connected with completing the forms, complain on the lack of employees trained in this respect and suggest organizing trainings.

The result of the meetings was the annual development of a joint position of the Committee in the form of a proposed level of subsidies from the state budget for the next year.

The government would inform the representatives of the minorities about the programs conducted within the Community Initiative EQUAL or Operational Program "Human Capital” (2007-2013.)

The report of MSWiA from 2007 became the basis of the debates and assessment of the situation of minorities in Poland.

A representative of the government noted that "(...) all enforcement acts required by the act were introduced relatively quickly and the act was translated into languages of national and ethnic minorities and the regional language (... $)^{29}$."

The representatives of minorities expressed anxieties and concerns regarding the statutorily guaranteed possibility of introducing bilingual names. The establishment of a mechanism of financing new name plaques was an important issue; the representative of the government assured that the costs would be covered by MSWiA.

${ }^{28}$ Minutes from the 5th meeting of the Joint Committee of the Government and National and Ethnic Minorities on 28.03.2007.

29 Minutes from the 9th meeting on 27.05.2008. 
The Joint Committee also dealt with the assessment of the introduction of the minority language - as an auxiliary language. At the 9th meeting the representative of the government informed that currently “(...) 20 gminas - from Opole, Podlaskie and Pomeranian Voivodeships were listed in the Official Register of Gminas in which an auxiliary language was used. ${ }^{30}$ "

The political issues also came up in the discussions of the Committee. As a result the Committee - as a whole - would issue statements.

As an example we could quote here the following fragments of the statement ${ }^{31}$ issued in connection with the behavior of members of the National Radical Camp (ONR) during the celebration of the anniversary of the Third Silesian Uprising on St. Anna Mountain in 2006 and 2007.

"The Committee shares the position of the Prosecutor's Office that all circumstances should be taken into account while assessing this most reprehensible event. In the opinion of the Committee the behavior of the members of ONR consisting in making gestures associated with fascism violates the constitutional order of the Polish State and the permission for such a behavior means tolerance of the fascist ideas and ideology which was the cause of the biggest tragedy of the 20th century."

The concern was palpable in the speech delivered by the representative of the Jewish minority who said: "(...) the Jewish community in Poland greatly appreciates the clear and firm condemnation of the acts of anti-Semitism issued by the highest authorities of Republic of Poland. At the same time, however, (...) is concerned about the tolerance of the All-Polish Youth (MW,) National Rebirth of Poland (NOP) propagating anti-Semitic slogans. There is a clear growth of intolerance manifested in onslaughts on Roma, destroying the Ukrainian minority objects and the growing level of intolerance in the media. ." $^{32}$

The mutual relations between the state authorities and minorities as well as the directions of the state policy towards those communities are clearly reflected in the minutes from the meetings of the Sejm Committee for National and Ethnic Minority Issues of the Sejm of the 4 th Term of Office. ${ }^{33}$

20 meetings of this Committee were held between Nov. 15, 2007 and July 23, 2008.

As a result of the analysis of the speeches of the representatives of national minorities, representatives of the government as well as invited experts the problems

${ }^{30}$ Ibidem.

${ }^{31}$ Minutes from the 7th meeting on 7.03.2008.

${ }^{32}$ Minutes from the 5 th meeting on 28.03.2007.

${ }^{33}$ Bulletin from the meetings of the Sejm Committee for National and Ethnic Minorities, www.sejm.gov.pl 
brought up by minorities can be grouped in a few major issues such as financial issues, discrimination issues regarding Roma and the issue of 'commemorations.'

The following is how the representative of the government evaluated the new law at the 2 nd meeting of the Committee: "The adoption of the Act on National and Ethnic Minorities and Regional Language of Jan. 6, 2005 was the reason of establishing clear principles of cooperation; it also allowed to meet a number of postulates which were put forward by national minorities. The last two years is the period of enforcement of the provisions of that act and stabilization of the cooperation with national and ethnic minorities as well as the period when we had the funds for that purpose. ${ }^{34}$ "

However, in respect of finances the representative of the Belarusian minority noted that "(...) the most important initiatives which were prepared by the Belarusian minority last year did not get financial subsidies. Not one penny was granted for the renovation of the Monastery in Supraśl (...) or the Festival of Belarusian Song (...) or the Orthodox Church music Festival in Hajnówka (...). The Przeglad Prawosławny monthly did not get subsidies either (...)."

The representative of Belarusians complained that there were no subsidies for the Belarusian Social and Cultural Society and no financing of the "Kyczera" meetings ${ }^{35}$.

The representative of the Ukrainian Historical Society at the 3rd meeting of the Committee noted that "(...) national minorities do not have any cultural institutions. Their cultural activities are in practice conducted through associations. That means that whereas the culture of the majority has a formal structure and its institutions which are systematically financed from the state or local budgets (...), the national minorities do not have such institutions which would be systematically financed ${ }^{36}$."

The representative of the Rusyn organization asked for the return of the title to the building of "Russian Dormitory," the representative of the Ukrainians demanded the Community Home in Przemyśl to be transferred to the Union of Ukrainians in Poland ${ }^{37}$.

The representative of the government justified the situation by the lack of money, priorities in the distribution of funds and finally by the decisions on their division made by the Committee upon agreement with the representatives of the minorities. At the same time the representative of the ministry reported that PLN 12 million from the state budget were used for the needs of minorities in 2007.

\footnotetext{
${ }^{34}$ Bulletin 107/ VI, meeting of the Committee on 19.12.2007, www.sejm.gov.pl

35 Ibidem.

${ }^{36}$ Bulletin 128/ VI, the meeting of the Committee 9.01.2008.

37 Bulletin 768 / VI, the meeting of the Committee 11.06.2008.
} 
The issues connected with the Romani community were frequently brought up at the meetings of the Committee; especially the 5th meeting was dedicated to those issues $^{38}$.

The representative of the government reported on the results of the implementation of the "Program for the Romani Community in Poland" which in the opinion of experts served a good role.

As a response of the authorities to the complaints of Roma on discrimination a Team for Romani Issues was established in MSWiA and the National Program of Prevention of Racial Discrimination, Xenophobia and Related Intolerance was implemented.

The representative of Romani organizations criticized placing the issues of national minorities in the structures of MSWiA saying that: "It is a continuation of the bad traditions from the times of $P R L$ where minorities were perceived as foreign elements threatening the sovereignty of the country and subject to militia control." The way of financing the Romani programs was also criticized: "The distribution of $80 \%$ of the funds to local governments does not decrease the level of exclusion of the members of our community and in fact it deepens that disproportion."

The issue of financing the name plaques and notices in minority language proved important to national minorities: Germans and Lithuanians and ethnic minorities - Kashubians and Rusyns. They complained that despite the existence of the act the government did not fully solve the problem of financing the new, bilingual name plaques and names of physical and graphical objects ${ }^{39}$.

The financial aspect of the issues connected with the guarantees of freedom of religion expressed in the postulates put forward by the leaders of minorities was important.

Muslims expressed the need to build a mosque in Warsaw and requested the return of the plot; the representatives of the Polish Autocephalous Orthodox Church expressed their concern that there is no act on return of property to that church, the Eastern Old-Rites Church demanded a statutory regulation of its legal situation and appointment of its clerical hierarchy in the Republic of Poland ${ }^{40}$. A reference was made to the law which enabled a quick return of property to the Roman-Catholic Church and evident negligence in respect of other denominations.

A comment of the representative of the Belarusian community is worth quoting at this place:

${ }^{38}$ Bulletin 578/VI, the meeting of the Committee on 23.04.2008.

39 Bulletin 128/ VI, meeting of the Committee on 9.01.2008; see: Lęk mniejszości, "Polityka”, No. 32, 9.08.2008.

${ }^{40}$ Bulletin 229/VI, meeting of the Committee on 6.02.2008. 
"When Tatars, Muslims, Russians, Old-Rites Followers, Belarusians, Rusyns or Orthodox Poles see the disproportion in the situation of their churches or religious organizations compared to the situation of the Roman-Catholic Church, they ask themselves a question why the state managed to solve such a huge problem as the return of property to the Roman-Catholic Church and the small problems of small communities still remain unsolved ${ }^{41}$ ?"

The representatives of the Orthodox Church questioned the provision on the obligation of making up for the days on which their absence at work was caused by the observing religious holidays by those communities.

The third group of examples of problems listed here which were raised at the meetings of the Committee includes the issues of so called 'commemorations.'

The difficult and complicated history of Poland of the time of wars and post-war reality was reflected in the need to commemorate the places of torture, genocide or building a necropolis.

The German minority in the region of Opole Silesia raised the need to build monuments commemorating the fallen German soldiers; the representatives of the government supported that view, however, as the representative of the Council for Remembrance of Struggle and Martyrdom put it "(...) there are also negative opinions regarding mainly commemorating German soldiers from the period of World War II to which there is and there will be no consent ${ }^{42}$."

In the opinion of the representatives of the state - "the biggest group of commemorations which ignite most controversy includes the Ukrainian commemorations. This is so because those issues evoke the most intense emotions ${ }^{43}$."

The Ukrainian minority put forward the postulate to change the inscriptions on the plaques and monuments commemorating the officers of the Internal Security Corps $(K B W$,$) Citizens' Militia (M O)$ and soldiers of the Polish Army who fell in the fights against "Ukrainian Insurgent Army (UPA) mobs." That community was affronted by such an inscription.

A design of monument dedicated to "The Orthodox Church Believers Living in Białostocczyzna Who Were Killed, Murdered and Lost in the Years 1939-1956" caused a lot of controversy between the authorities and representatives of the minorities. The representatives of the government did not grant their consent for financing the design explaining that the criterion applied would divide the local community ${ }^{44}$.

\footnotetext{
${ }^{41}$ Bulletin 173/VI, meeting of the Committee on 22.01.2008

${ }^{42}$ Bulletin 957/VI, meeting of the Committee on 10.07.2008

43 Ibidem

${ }^{44}$ Bulletin 1011/VI, meeting of the Committee on 23.07.2008
} 
The 'historical policy' and its implementation by Polish authorities sometimes caused dissatisfaction - the representative of the Slovak organization said: "We asked for an explanation of the reasons of commemoration of Józef Kuraś "Ogień" in Zakopane. The Chancellery of the President of the Republic of Poland refused to deal with that matter due to its political aspect ${ }^{45}$."

During the meetings of the Committee the representatives of the government accused the minority organizations of very often incorrectly completing the applications for subsidies (which affects the date when the money is transferred) and claimed that they do not undertake steps on their own to raise funds from sources other than subsidies.

It was also noted that despite organizing minority language courses - the Czechs, Russians, Karaites, Tatars and Roma do not attend those classes.

It should be added that in 2008, 855 school institutions offered teaching minority language classes on which activity the local governments received PLN 132.5 million operated in Poland.

In the opinion of the Commissioner for Civil Rights Protection who was filed with complaints by some minorities - "Generally, the assessment of the activities conducted by Polish bodies of public administration, local administration in the matters regarding national and ethnic minorities is positive. (...) They correctly fulfill the duties imposed on them by the Constitution of the Republic of Poland or by the statutory acts ${ }^{46}$."

The issues of mutual relations between state authorities and minorities can be also illustrated by a local level example. It should be stressed that each voievodeship in the Republic of Poland has slightly different problems due to its specificity and the percentage of national and ethnic minorities living there.

For instance - in the opinion of the Lower Silesia Voivode - "(...) the situation in our voivodeship is better than in other voivodeships - e.g. all Romani education assistants who had contracts of employment for a definite term until December 2006 had the contracts extended by the end of the school year 2006/2007 and their employment already in 2006 was financed from the subsidies. (...) I would like to inform that in 2006 the Lower Silesian Voivodeship received the amount of about PLN 900 thousand from the special purpose provision of the "Program for Romani community in Poland" for activities including: education, health, repairs, security, culture, elimination of unemployment, civic activation of Roma and promotion of knowledge about Roma,

${ }^{45}$ Bulletin 173/VI, meeting of the Committee on 22.01.2008

${ }^{46}$ Ibidem. 
and the amount of increased educational subsidy for extra educational activities for Romani children reached in 2006 PLN 2,127,6844".

Furthermore, in the note attached to the letter the Lower Silesia Voivode informed that about 4.5 thousand Roma live on his territory, including 600 school children for whom too small funds were granted for financing remedial classes.

What caused the Voievode's concern was also the fact that Romani assistants are released for the period of vacation, they do not feel secure about their employment and sometimes "they are not treated by the teaching staff as partners in the process of improving the education of Romani children."

The Lower Silesia Voivode Plenipotentiary for the issues of national and ethnic minorities confirmed in June 2008 the underprivileged situation of Romani assistants saying:

"(...) I would like to inform that on the territory of Lower Silesian Voievodeship we have voted cases which can be described as discriminatory practices against Romani assistants working in schools (...) The fact that during the meeting of the teaching staff one of the principals warned the teachers against leaving a Romani assistant alone in the teachers' room because there are a lot of important documents there shall be considered an especially evident case of discrimination ${ }^{48 .}$."

\section{CONCLUSIONS}

The transformation of the Polish system which started in 1989 has totally changed the approach of the state authorities towards national and ethnic minorities living in the Republic of Poland.

The new, democratic state has implemented a "new philosophy" in the approach towards minority issues - the minorities have been 'recognized' which was manifested by legal acts and new institutions guaranteeing the protection and enforcement of those rights. Furthermore, the national and ethnic minorities started to publicly expose their cultural distinctness.

The attempts of assimilation that is marginalization of the problems of minorities have been given up altogether.

47 Letter of the Lower Silesia Voivode Krzysztof Grzelczyk to Jan Kochanowski, Ph.D., Commissioner for Civil Rights Protection from 13.02.2007, file no. SO XI 6522-7(1) 07 MR.

${ }^{48}$ Letter of the Lower Silesia Voivode Plenipotentiary to Deputy Director of the Department for Religious Denominations and National and Ethnic Minorities of MSWiA from 17.06.2008, file no. SOXI6522-15(1)/08DT. 
Poland with its international obligations arising from the conventions on the protection of human rights it signed has adjusted its internal law to the world standards.

The Polish Constitution of 1997 guaranteed national and ethnic minorities extensive rights to protect and maintain their own language, customs, tradition and culture. The constitutional principles have been extended by the acts and enforcement laws guaranteeing the minorities the enforcement of the rights granted to them.

The development of new law was accompanied by permanent institutional solutions.

New offices have been appointed in the structures of the state administration whose purpose of operations was to secure the enforcement of adopted regulations.

The representatives of minority organizations have been granted a permanent place in the Polish Parliament: the Committee for National and Ethnic Minorities - in the Sejm and the Joint Committee of the Government and National and Ethnic Minorities - in the government.

The minorities have been recognized as a subject of political life and they have been granted a number of special rights.

A partnership dialog of the state authorities with representatives of the minorities has resulted in a new perspective at the needs of those communities.

By the end of the 1990s Polish citizens whom the provisions of law granted full freedom in identification with a national or ethnic minority were fully empowered - legally, politically and institutionally.

In the social sphere the state guaranteed the minorities protection of their identity - culture, language, religion or tradition in its broad meaning.

The new, democratic Republic of Poland 'has been learning how to deal' with minorities -adjusting its legal regulations to the needs of those groups while outlining the limitations of the granted freedoms at the same time.

The new perspective the state had of the ethnic diversity of society and appreciation of the aspirations of members of ethnic groups was manifested in the act on national and ethnic minorities and regional language. The state allowed the use of a minority language in gminas where minorities represent at least $20 \%$ of the total population, provided for the introduction of bilingual name plaques and the use of Kashubian as a regional language.

Relations between the state authorities and representatives of minorities have been good. The main problems which have been raised by the representatives of minority organizations include financial issues in spite of the fact that the state budget every year has earmarked bigger and bigger subsidies for minority associations and organizations. 
Ethnic discrimination has affected the Romani community in Poland and that is why the state authorities, being aware of the difficult social and economic situation of Roma, have implemented extensive programs preventing exclusion.

The issues of 'commemorations' have become a sui generis political problem for the state - activities undertaken by minorities on the rising 'historical policy' wave.

The representatives of the government, understanding the complexity of our history and the delicacy of the problems, carefully mediated with the leaders of minorities the issue of building monuments, renovation of cemeteries or bilingual plaques, however, they firmly refused the consent to commemorate the persons connected with fascist or communist ideologies considered criminal doctrines in the world.

Three stages can be distinguished in the policy of the state authorities towards national and ethnic minorities: the years 1989-1990 - which can be seen as a period when the minorities were granted subjective rights in the institutional, legal and political spheres; the years 1990-2005 - the time of implementation of the postulates of minority organizations which articulated their needs and the third stage (after 2005) which began with the act on national and ethnic minorities and regional language - when language privileges were granted.

In all three stages the policy of the authorities towards minorities was consistent and the set course was followed.

It can be then summed up that at present the state authorities: maintain and develop the cultural identity of national and ethnic minorities, maintain the regional language, enforce equality regardless the ethnic origin, prevent discrimination and spread knowledge about ethnic and cultural diversity of Poland.

Compared to the data collected in the census in 1946, the number of national minorities in Poland decreased but it should be noted that over the last few years there has been an 'explosion' of ethnicity with numerous festivals, concerts, regional cuisine days or presentations of cultural heritage organized by the communities with the financial support of the state.

One could risk a proposition that the national and ethnic minorities together with public presentation of their own culture have become an inherent part of Polish awareness and the great majority of Polish population considers those communities an integral part of the cultural diversity of the country.

This is undoubtedly the effect of the national policy enforced by the state authorities. 
Despite the fact that compared with the data the number of national and ethnic minorities in Poland decreased, there could be seen a dynamic growth of the number of organizations, schools with foreign language, other forms of activities - festivals, Poland after 1989 has been building a legal system protecting human and civil rights - the regulations regarding national minorities became its part. 